Vitalii Polovenko (2019) Analiz vplyvu zovnishnikh ta vnutrishnikh faktoriv na zhyvuchist' skladiv tylovoho zabezpechennya [Analysis of the impact of external and internal factors on the survivability of warehouses of supply support]. Social development \& Security. 9(4), 143 - 151. DOI: http://doi.org/10.33445/sds.2019.9.4.11

\title{
Аналіз впливу зовнішніх та внутрішніх факторів на живучість складів тилового забезпечення
}

\section{Віталій Половенко}

Національний університет оборони Украӥни імені Івана Черняховського, проспект Повітрофлотський, 28, м. Київ-049, 03049, Украӥна, e-mail: polovenko469@gmail.com, здобувач

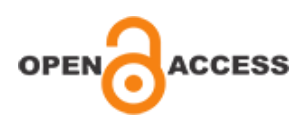

Article history:

Received: June, 2019

1st Revision: July, 2019

Accepted: August, 2019

УДК: 355.41(477)
Анотація: Практичне вирішення завдань забезпечення військ матеріальними засобами покладене на склади тилового забезпечення. Тому в статті розглядаються питання впливу зовнішніх та внутрішніх факторів, як вирішальний чинник впливу на виконання завдань тилового забезпечення військ. Автор досліджує один з важливих показників - живучість складів тилового забезпечення. Підкреслюється актуальність та перспективність у розробленні методики, яка б враховувала вплив зовнішніх і внутрішніх факторів на живучість складів.

Метою статті $є$ аналіз впливу зовнішніх та внутрішніх факторів на живучість складів тилового забезпечення. Автор виявив протиріччя, які виникають під впливом зовнішніх та внутрішніх факторів та надає їхню класифікацію за групами.

Використання результатів дослідження допоможе, зокрема, в оцінці наслідків впливу масштабу та характеру дій з боку противника, відносних втрат матеріальних засобів на живучість складів, а також надає можливість встановити вимоги до складів тилового забезпечення та процесу забезпечення військ матеріальними засобами, підвищити живучість складів та завчасно здійснювати підготовку складів тилу до майбутніх бойових дій, враховуючи зовнішні та внутрішні фактори.

Ключові слова: живучість складів, забезпеченість військ матеріальними засобами, тилове забезпечення.

\section{1. Формулювання проблеми}

1.1 Постановка проблеми. Проведений аналіз досвіду збройних конфліктів початку XX сторіччя надає змогу зробити висновок, що тилове забезпечення військ відіграє важливу роль у виконанні завдань військами під час проведення операцій [1]. Практичне вирішення завдань забезпечення військ матеріальними засобами (М3) покладене на склади тилового забезпечення та підрозділи підвезення матеріальних засобів. Останнім часом підвищилися вимоги до живучості складів. Саме живучість складів стає вирішальним чинником виконання завдань тилового забезпечення. Урахування досвіду тилового забезпечення в збройних конфліктах останніх десятирічь $\epsilon$ актуальним завданням. При цьому важливим є врахування впливу зовнішніх та внутрішніх факторів [2, 3] на живучість складів тилового забезпечення. 


\section{2 Аналіз останніх досліджень та публікацій}

Тиловому забезпеченню військ присвячено досить багато джерел, але більша частина їх застаріли, бо відображають стан тилового забезпечення військ до створення Збройних Сил України [4-7]. При цьому живучості складів тилового забезпечення в науковій літературі достатньої уваги не приділяється.

\section{3. Постановка завдання}

Метою статті $\epsilon$ аналіз впливу зовнішніх та внутрішніх факторів на живучість складів тилового забезпечення.

\section{2. Виклад основного матеріалу}

2.1. У процесі свого функціонування склади тилового забезпечення виконують певні завдання, зокрема забезпечення частин i підрозділів озброєнням і військовою технікою (ОВТ), ракетами, боєприпасами, пальномастильними матеріалами, військово-технічним майном тощо. На спроможність системи забезпечення виконувати покладені на неї завдання вагомий вплив здійснює живучість складів тилового забезпечення. У свою чергу, на склади тилу впливають відповідні фактори, які умовно поділяються на зовнішні та внутрішні й виявляють себе у конкретних умовах обстановки [3].

2.2. Під живучістю складів тилового забезпечення будемо розуміти їх властивість зберігати, а за необхідності своєчасно відновлювати й нарощувати здатність до виконання завдань в умовах негативного впливу на них різних (внутрішніх та зовнішніх, позитивних і негативних) факторних груп.

2.3. Зовнішніми факторами, що здійснюють відчутний вплив на склади тилового забезпечення та визначають їх живучість у найбільш загальному вигляді, є фактори, які можна об'єднати у такі групи:

перша група визначає масштаб і характер впливу на свої війська та склади з боку противника;

друга група відображає характер дій своїх військ, особливості їх застосування, співвідношення сил сторін;

третя група враховує технічний рівень та особливості конструкції ОВТ, що перебувають на озброєнні військ противника та своїх військ;

четверта група пов'язана із середньодобовими відносними втратами основних видів ОВТ та їх розподілом;

п'ята група визначається запасами МЗ, які потрібно створити у військах i на складах на початок і кінець операції;

шоста група передбачає можливі витрати та втрати М3 у військах і на складах під час бойових дій;

сьома група містить фізико-географічні умови, пору року, час доби, погодні умови. 
2.4. Механізм впливу зовнішніх факторів на живучість складів тилового забезпечення виявляється завдяки аналізу низки протиріч, що спостерігаються під час забезпечення військ МЗ.

Протиріччя між потребами військ, з одного боку, й можливостями складів тилового забезпечення - 3 другого, виникає під впливом зовнішніх факторів першої, другої та третьої груп, що відображають тенденцію до збільшення потреби у кількості та якості МЗ у арміях країн світу, а також факторів п'ятої та шостої груп, які пов'язані з тенденцією до зростання витрат МЗ. Зазначені фактори сукупно зумовлюють необхідність збільшення запасів М3, забезпечення їх експлуатації, зокрема зберігання, обслуговування та ремонту.

Протиріччя між достатністю (необхідною кількістю) М3, у тому числі запасів МЗ, з одного боку, й економічністю системи складів тилового забезпечення - 3 другого, зумовлюється зовнішніми факторами першої та другої груп, зокрема спроможністю противника досягати високого ступеня вогневого ураження військ, які йому протидіють, i, відповідно до цього, факторами четвертої групи - зростаючою кількістю втрат ОВТ, у тому числі засобів тилу. Зазначені фактори зумовлюють необхідність розгортання достатньої кількості складів тилового забезпечення з урахуванням обмежених фінансових витрат на їх створення та виконання ними поставлених завдань. Звідси, зокрема, випливає необхідність обгрунтування найбільш доцільного способу використання обмежених фінансових ресурсів, які виділяються для створення потрібної кількості складів.

Результатом дії розглянутих факторів та фінансових обмежень є також невідповідність між необхідними обсягами й термінами подачі у війська М3, 3 одного боку, та можливостями складів тилового забезпечення - 3 іншого. Ця невідповідність виявляє себе у відсутності необхідної кількості та ємності складів тилового забезпечення для вирішення завдань забезпечення військ.

Протиріччя між своєчасністю забезпечення військ МЗ та живучістю складів зумовлені дією факторів першої та другої груп, які пов'язані 3 необхідністю своєчасного вирішення завдань складами тилового забезпечення (зокрема, за рахунок наближення складів до військ) в умовах вогневого впливу противника на них, який зростає при наближенні до переднього краю. У зв’язку 3 цим, враховуючи можливості засобів вогневого ураження противника, можна говорити про відсутність “недосяжного тилу” в побудові сучасних угруповань військ.

2.5. Розглянуте протиріччя межує 3 невідповідністю між потрібним розташуванням районів розгортання складів тилового забезпечення стосовно забезпечуваних частин і підрозділів, що гарантує найбільшу ефективність їх використання, 3 одного боку, та чинними нормативними вимогами щодо застосування складів тилового забезпечення - 3 іншого. Згадана невідповідність, у свою чергу, викликає необхідність обгрунтування тактичних нормативів застосування складів тилового забезпечення та визначення раціонального розташування районів їх розгортання. Перебуваючи у цих районах, склади тилового забезпечення об'єднаних угруповань військ (ОУВ) будуть здатні своєчасно забезпечувати частини й підрозділи М3, не підпадаючи 
під вплив системи вогневого ураження противника, або цей вплив буде значно зниженим чи малоймовірним. Саме такі, обгрунтовані, нормативи та раціональне розташування районів розгортання складів тилового забезпечення насамперед надають можливість досягти необхідного рівня живучості цих складів.

Протиріччя між живучістю складів, на яких зберігаються М3, та недостатньою величиною наявних запасів МЗ, що використовуються для забезпечення потрібної живучості системи забезпечення, зумовлені факторами першої, другої та четвертої груп, зокрема здатністю противника проводити тривалі за часом операції та завдавати під час їх проведення потужних ударів, що можуть призвести до значних втрат у ОУВ, у тому числі, на складах тилового забезпечення. Це протиріччя викликає необхідність в обгрунтуванні потрібної величини додаткових запасів МЗ для забезпечення військ.

Далі розглянемо більш детально групи зовнішніх факторів, які здійснюють найбільший вплив на склади тилового забезпечення.

2.6. Оцінювання масштабу й характеру дій з боку противника на війська, які йому протидіють, урахування характеру дій сторін, особливостей застосування військ та співвідношення сил сторін передбачають визначення тенденцій у розвитку збройної боротьби.

Для наземного етапу операції на сьогодні найбільш характерним є значне зростання глибини ешелонування угруповання військ унаслідок збільшення дальності дії засобів ураження сторін. Це переважно відбувається за рахунок збільшення відстані від лінії зіткнення сторін до складів тилового забезпечення 3 метою їх збереження від ударів протидіючої сторони. Крім того, має місце суттєве збільшення інтенсивності та ефективності ударів обох сторін i підвищення, у зв’язку 3 цим, важливості організації та здійснення матеріального забезпечення.

Під час оцінювання співвідношення сил сторін на сучасному етапі розвитку воєнного мистецтва перевага надається якісним показникам за відносного зменшення ваги кількісних характеристик. У цьому сенсі важливу роль відіграє наявність сучасних засобів тилу в арміях сторін.

Зміни у загальних втратах засобів тилу, в тому числі і на складах, у сучасних бойових діях пов'язані насамперед із застосуванням нових засобів розвідки й вогневого ураження та мають тенденцію до збільшення.

Аналіз виходу з ладу засобів тилу під час збройних конфліктів і локальних війн кінця XX - початку XXI сторіччя, а також прогнози вітчизняних i закордонних спеціалістів виявляють як тенденцію до збільшення, так і зміни у структурі втрат засобів тилу у бік зростання сильних пошкоджень i безповоротних утрат. Водночас, незважаючи на відносне зменшення кількості середніх і слабких пошкоджень, як свідчить досвід останніх років, роль поточного ремонту та середнього ремонту не зменшується, бо саме ці два види ремонту забезпечують найшвидше повернення до строю пошкоджених засобів тилу.

Коли ведуться бойові дії, витрати МЗ мають тенденцію до зростання, а це відповідно призводить до потреби у збільшенні їх запасів, зокрема ракет i 
боєприпасів, у сучасних арміях. Звідси, середньодобові відносні втрати МЗ засобів на складах теж зростають.

2.7. Досвід виконання завдань системою тилового забезпечення у збройних конфліктах сучасності свідчить про те, що сьогодні $є$ обов'язковою завчасна, ще до початку збройного конфлікту, підготовка складів тилу до майбутніх бойових дій.

Кількісно вплив зовнішніх факторів на склади тилового забезпечення виявляється, зокрема, через показник, що характеризує їх живучість. При цьому показник живучості повинен розглядатися як комплексний (інтегральний) показник, який не лише характеризує в загальному плані їх властивість зберігати, а за необхідності своєчасно відновлювати й нарощувати здатність до виконання завдань в умовах негативного впливу на них зовнішніх факторів, але при цьому конкретно враховує не тільки вогневий вплив противника на склади тилу, а й їх спроможність досягати достатності й своєчасності в забезпеченні потреб військ МЗ різних видів. Отже, на показник живучості здійснюють вплив зовнішні фактори першої, другої та п’ятої груп.

Визначене потребує урахувати здатність противника до виявлення та вогневого ураження складів тилового забезпечення, в результаті чого матимуть місце їх втрати, та потреби військ у МЗ протягом операції ОУВ. Звідси випливають вимоги до складів тилового забезпечення щодо важливості маскування та періодичності їх переміщення.

Вплив на живучість складів тилового забезпечення ОУВ не обмежується лише зовнішніми факторами. Значну “вагу” серед факторів впливу мають внутрішні фактори, дія яких виявляє себе “зсередини”. Вона виникає на межі взаємодії всіх складових досліджуваного об’єкту як між собою, так і 3 об'єктами, з якими вони взаємодіють.

2.8. Внутрішніми факторами стосовно складів тилового забезпечення, що здійснюють найбільш суттєвий вплив на їх живучість, є фактори, які можна узагальнити та об'єднати у такі групи:

перша група містить фактори, що виявляють себе під час взаємодії складів тилового забезпечення і військ, кількість цих складів, наявність на них запасів МЗ та стан цих засобів;

друга група об’єднує фактори, що виникають як результат функціонування за призначенням та взаємодії між собою певних складових системи тилового забезпечення. Ця група охоплює:

кількість транспортних засобів для підвезення МЗ;

наявність, стан і можливості підрозділів ремонту й технічного обслуговування засобів тилу щодо їх відновлення, 3 урахуванням певних обмежень щодо їх застосування;

третя група визначає нормативи застосування складів тилового забезпечення, у тому числі тактичних, засобів підвезення М3 й ін.;

четверта група містить воєнно-економічні можливості країни щодо забезпечення військ МЗ.

Аналіз виконання завдань складами тилового забезпечення під впливом внутрішніх факторів показав, що цей вплив викликає появу протиріч між 
певними складовими процесу матеріального забезпечення. Внутрішні фактори впливають на процес матеріального забезпечення безперервно, виявляючи 3 часом різні складові свого впливу. Співвідношення між цими складовими, інтенсивність впливу окремих факторів постійно змінюються, формуючи згадані протиріччя, що мають як відносно стабільний (детермінований), так i змінний, навіть випадковий прояв.

2.9. Механізм дії внутрішніх факторів на живучість складів тилового забезпечення простежується через протиріччя між:

потребами військ 3 одного боку, й можливостями складів тилового забезпечення, з іншого, яке виникає під впливом внутрішніх факторів першої, другої та четвертої груп. Потреби військ формуються як під впливом противника (через зовнішні фактори), так і відповідно до необхідності мати достатні можливості військ (перша група внутрішніх факторів), що визначається, насамперед, воєнно-економічними можливостями країни (об’єктивна складова), які становлять четверту групу внутрішніх факторів. Це протиріччя поглиблюється через недостатню живучість складів тилового забезпечення (друга група внутрішніх факторів) насамперед тому, що наявні сили й засоби не можуть бути використані в повному обсязі й т. ін. Звідси, зокрема виникають вимоги до маскування складів, необхідності виконання робіт щодо пожежовибухобезпеки складів та ін.;

своєчасністю забезпечення військ МЗ, з одного боку, та живучістю складів тилового забезпечення - 3 іншого. Це протиріччя формується під впливом внутрішніх факторів усіх груп через необхідність мати потрібну кількість М3 для забезпечення військ (перша група), певні можливості складів тилового забезпечення (друга група), що може бути досягнуто лише завдяки достатнім воєнно-економічним можливостям країни (четверта група) й виявлятися протягом потрібного часу та у визначені терміни. Водночас, застосування складів тилового забезпечення повинно відбуватися 3 використанням прийнятних нормативів їх застосування (третя група). Нормативи повинні визначати необхідну відстань складів тилового забезпечення від лінії стикання сторін і тим самим, зокрема, забезпечувати живучість згаданих складів;

необхідною кількістю (достатністю) складів тилового забезпечення, в тому числі запасів М3 на цих складах, 3 одного боку, й економічністю системи складів тилового забезпечення - 3 іншого. Протиріччя, вочевидь, виникає в результаті взаємодії внутрішніх факторів першої, другої та четвертої груп;

здатністю складів тилового забезпечення виконувати завдання під час бойових дій, 3 одного боку, та недостатньою величиною запасів МЗ, що використовується для забезпечення сталого функціонування складів тилового забезпечення під час бойових дій - 3 іншого. Протиріччя відповідає другій групі внутрішніх факторів і вимагає від економіки держави (четверта група) забезпечити потрібну величину запасів М3.

2.10. Розглянуті внутрішні фактори відповідно до кожного протиріччя викликають появу невідповідностей між:

необхідними обсягами й термінами подачі до військ М3, відновлення засобів тилу (перша група), з одного боку, й існуючими можливостями, та 
кількістю складів тилового забезпечення і транспортних засобів (друга група) 3 іншого;

потрібним положенням районів розгортання складів тилового забезпечення стосовно військ, що забезпечує найбільшу їх живучість (третя група), з одного боку, та чинними нормативами застосування складів тилового забезпечення -3 іншого;

сучасними способами застосування складів тилового забезпечення (друга та третя група), з одного боку, та змістом і вимогами існуючих керівних документів - 3 іншого.

Негативний вплив цих невідповідностей призводить до зниження живучості складів тилового забезпечення.

\section{3. Висновки і перспективи подальших досліджень}

Отже, у статті проведено аналіз впливу на живучість складів тилового забезпечення ОУВ зовнішніх та внутрішніх факторів. Виявлено протиріччя, які зумовлюють необхідність врахування впливу окремих факторів на живучість складів тилового забезпечення, надано класифікацію груп зовнішніх та внутрішніх факторів.

Перспективи подальших досліджень у цьому напрямку пов'язані з розробленням методики, яка враховувала б вплив зовнішніх i внутрішніх факторів на склади тилового забезпечення.

\section{Author details (in Russian)}

\section{Анализ влияния внешних и внутренних факторов на живучесть складов тылового обеспечения}

\section{Виталий Половенко}

Наџиональный университет обороны Украины имени Ивана Черняховского, пр-кт Воздухофлотский, 28, г. Киев-049, 03049, Украина,

e-mail: polovenko469@gmail.com, соискатель.

Аннотация: Практическое решение задач обеспечения войск материальными средствами возложено на склады тылового обеспечения. Поэтому в статье рассматриваются вопросы влияния внешних и внутренних факторов, как решающий фактор выполнения задач тылового обеспечения войск. Автор определяет один из главных показателей - живучесть складов тылового обеспечения. Подчеркивается актуальность и перспективность в разработке методики, которая учитывала бы влияние внешних и внутренних факторов на живучесть складов.

Целью данной статьи является анализ влияния внешних и внутренних факторов на живучесть складов тылового обеспечения. Авторы обнаружили противоречия, обуславливающие необходимость учета влияния внешних и внутренних факторов и предоставили их классификацию по группам.

Использование результатов исследования поможет в оценке влияния на живучесть складов масштаба и характера действий со стороны противника, относительных потерь 
материальных средств на складах, а также предоставляет возможность установить требования к складам тылового обеспечения и материальному обеспечению войск, повысить живучесть складов и заблаговременно осуществлять подготовку складов тыла к будущим боевым действиям, учитывая внешние и внутренние факторы.

Ключевые слова: живучесть складов, обеспеченность войск материальными средствами, тыловое обеспечение.

\section{Author details (in English)}

\section{Analysis of the impact of external and internal factors on the survivability of warehouses of supply support}

\section{Vitalii Polovenko}

The National Defense University of Ukraine named after Ivan Cherniakhovskyi, 28, Povitroflotsky ave., Kyiv-049, 03049, Ukraine, e-mail: polovenko469@gmail.com, Ph.D. student.

Abstract: The practical solution of the tasks of providing troops with material resources is entrusted to logistic support warehouses. Therefore, the article deals with the influence of external and internal factors as a decisive factor in the fulfillment of the tasks of logistical support for the operational grouping of troops. The authors define one of the main problems - the survivability of logistics warehouses. It emphasizes the relevance and prospects in developing a methodology that would take into account the influence of all factors on the warehouses.

The purpose of this article is to analyze the influence of external and internal factors on the survivability of logistics depots for the operational group of troops. The authors found contradictions that necessitate taking into account the influence of individual external and internal factors and provided their classification into groups.

Using the results of this study will help in assessing the scale and nature of actions by the enemy, the relative loss of material resources in warehouses, as well as establish requirements for logistics, stability of process components and timeliness of material support for troops, increase survivability of warehouses and prepare future combat operations, taking into account external and internal factors.

Keywords: survivability of warehouses, material resources, logistics, operational grouping of troops.

\section{Використана література}

1. Требин М. П. Войны ХХІ века. Минск: ООО Харвест, 2005. 608 с.

2. Бочков Е. А., Капшитар В. Г. Развитие системы тылового обеспечения РККА накануне Великой Отечественной войны. Военная мысль. 2005. № 9. С. 58-67.

3. Теоретичні основи аналізу, моделювання та синтезу системи матеріально-технічного забезпечення як просторово-розподіленої систем / Романченко I. С., Шуєнкін В. О., Хазанович О. І., Марко І. Ю. Київ: ЦНДІ ЗС України, 2013. 221 с.

4. Владимиров В. Тыловое обеспечение механизированной дивизии Сухопутных войск США. Зарубежное военное обозрение. 1990. № 3. С. 21-27.

5. Шмаков И. Тыловое обеспечение Сухопутных войск США. Зарубежное военное обозрение. 2005. № 10. С. 17-22.

6. Голушко И. М., Варламов Н. В. Основы моделирования и автоматизации управления тылом. Москва: Воениздат, 1982. 237 с. 
7. Голушко И. М. Развитие тыла Советских Вооруженных Сил 1918-1988 / Голушко И. М., Балдин В. А., Бородулин В. И. и др.; под ред. Родина В. Н. Моква: Воениздат, 1989. $312 \mathrm{c.}$

\section{References}

1. Trebin M.P. Wars of the XXI century. Minsk: Harvest LLC, 2005. 608 p. [in Belarus]

2. Bochkov E. A., Kapshitar V. G. (2005) Development of the logistics system of the Red Army on the eve of the Great Patriotic War. Military Thought. No. 9. P. 58-67. [in Russia]

3. Theoretical foundations of the analysis, modeling and synthesis of the system of material and technical protection yak open space systems / Romanchenko I. S., Shuankin V. O., Khazanovich O. I., Marko I. Yu. Kyiv: TSNDI ZS Ukraine, 2013. 221 p. [in Ukraine]

4. Vladimirov V. Logistics of the mechanized division of the US Land Forces. Foreign Military Review. 1990. No. 3. P. 21-27. [in Russia]

5. Shmakov I. Logistics of the US Ground Forces. Foreign Military Review. 2005. № 10. P. 17-22.

6. Golushko I. M., Varlamov N.V. Basics of modeling and automation of rear control. Moscow: Military Publishing, 1982. 237 p. [in Russia]

7. Golushko, I. M. Development of the rear of the Soviet Armed Forces 1918-1988 / Golushko I. M., Baldin V. A., Borodulin V. I., and others; by ed. Rodina V. N. Moscow: Military Publishing, 1989. 312 p. [in Russia] 